University of Nebraska - Lincoln

DigitalCommons@University of Nebraska - Lincoln

Adam Liska Papers

Biological Systems Engineering

2011

Energy and Climate Implications for Agricultural Nutrient Use Efficiency

Adam J. Liska

University of Nebraska-Lincoln, aliska2@unl.edu

Richard K. Perrin

University of Nebraska - Lincoln, rperrin@unl.edu

Follow this and additional works at: https://digitalcommons.unl.edu/bseliska

Part of the Biological Engineering Commons

Liska, Adam J. and Perrin, Richard K., "Energy and Climate Implications for Agricultural Nutrient Use Efficiency" (2011). Adam Liska Papers. 9.

https://digitalcommons.unl.edu/bseliska/9

This Article is brought to you for free and open access by the Biological Systems Engineering at DigitalCommons@University of Nebraska - Lincoln. It has been accepted for inclusion in Adam Liska Papers by an authorized administrator of DigitalCommons@University of Nebraska - Lincoln. 


\title{
Energy and Climate Implications for Agricultural Nutrient Use Efficiency
}

\author{
Adam J. Liska and Richard K. Perrin
}

\section{Contents}

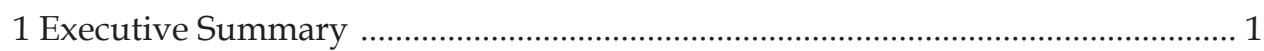

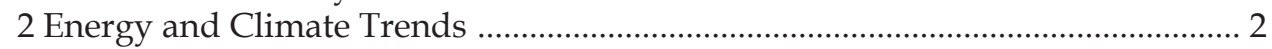

3 Agricultural Nutrient Use Efficiency and Biofuels ............................................ 5

4 Land Limitations and Global Agricultural Production .................................... 11

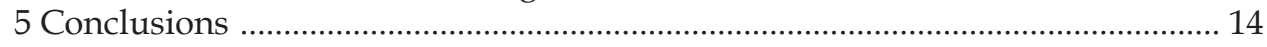

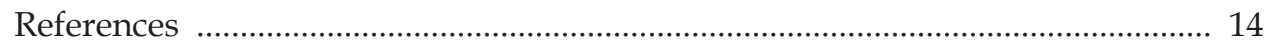

\section{Executive Summary}

Energy and climate change are beginning to dominate the global political agenda and will drive policy formation that will shape the future of agriculture. Energy issues threaten national security and economic stability, as well as access to lowcost nutrient inputs for agriculture. Climate change has the potential to cause serious disruption to agricultural productivity. Paradoxically, nutrient use in agriculture to increase crop yields has the potential to negatively impact climate. This chapter will discuss recent and future energy and climate trends, the relationships between agricultural nutrient use efficiency and biofuels, and how global land limitations will shape agriculture in the future. Comparative gross energy yield and nitrogen use efficiency for ethanol production from crop residue, switchgrass, grain sorghum, sweet sorghum, and corn grain is presented, showing small differences in nitrogen use efficiency, but large differences in gross energy yields. In addition to considering the need to increase crop productivity to meet the demands of a growing population and bioenergy, agricultural nutrient use efficiency must be reconsidered with respect to the important energy and climate challenges shaping agriculture today. 


\section{Energy and Climate Trends}

Nutrient application in agriculture is essential to maintain a sufficient food supply for a growing global population and to meet an increased demand for bioenergy. The fixation of atmospheric nitrogen $(\mathrm{N})$ by the Haber-Bosch process has enabled higher crop yields necessary to support the growth of global population by roughly three billion people in the twentieth century, or almost half of humanity. ${ }^{20}$ Energy is required to process, deliver, and apply nutrients to land, which is costly and contributes to climate change. Increased nutrient use efficiency is essential to increase crop productivity and energy efficiency of bioenergy production in a sustainable manner while limiting negative environmental impacts and reducing costs. ${ }^{8}$

Energy issues are beginning to dominate the global political agenda. First, there is growing concern that global production of easily accessible oil is nearing its peak rate. ${ }^{13,56}$ Global oil production is dominated by giant oil fields, with the 500 largest fields contributing over $60 \%$ of production. ${ }^{27}$ In 2008,580 of the 651 largest oil fields globally were reported to have passed their peak production rate and are now producing an average of about $6 \%$ less oil per year. ${ }^{27,29}$ In accordance with reported declining trends, an independent analysis from Uppsala University in Sweden found that global oil production will decline from 84 million barrels per day (mb/day) (including natural gas liquids) in 2007 to roughly $76 \mathrm{mb} /$ day by $2030 .^{2}$ In contradiction to these findings, official analysis from the International Energy Agency (IEA) optimistically anticipates that petroleum production will continue to increase through 2030, reaching a level $20 \%$ higher than current levels. ${ }^{30}$ The U.S. Energy Information Administration (EIA) also anticipates an increase in production over this period of about $15 \% .{ }^{15}$ Contrary to these assertions, the Swedish study states that historic trends of reduced field productivity will continue in the future at the same rate, which means lower productivity than other estimates that are more likely to be politically influenced. These conflicting expectations add uncertainty and volatility to world energy markets that are already vulnerable to political and economic vagaries.

Increases in oil demand that exceed rates of supply increase will cause oil prices to climb. By 2030, both the IEA and EIA project oil to reach about $\$ 190$ per barrel in nominal dollars (\$115-\$130 in 2008 dollars). Some suggest, however, that the recent oil price spike in 2008 to $\$ 147$ per barrel (compared to roughly $\$ 80$ per barrel in December 2009) has stimulated increased conservation and adaptation which may keep oil prices relatively lower in the near term due to reduced demand. ${ }^{45}$ The current recession has also reduced demand for oil. Nonetheless, oil prices and the trend in total cost of U.S. crude oil imports are likely to continue to increase (Figure 1). In 2007 with oil at $\$ 70$ per barrel, the U.S. trade deficit in petroleum products was $\$ 293$ billion, or 36\% of the total trade deficit of $\$ 819$ billion. ${ }^{62}$ Increasing production of nonconventional sources of petroleum such as oil (tar) sands from Canada will also help maintain petroleum supply, ${ }^{29}$ while production from current major fields is declining. Oil sands could contribute as much as $20 \%$ of U.S. gasoline supply by $2020{ }^{41}$

Global growth in population and the world economy have required greater energy use to sustain improving living standards. With increasingly narrow margins between energy supply and demand, analysis suggests that disruption of the 


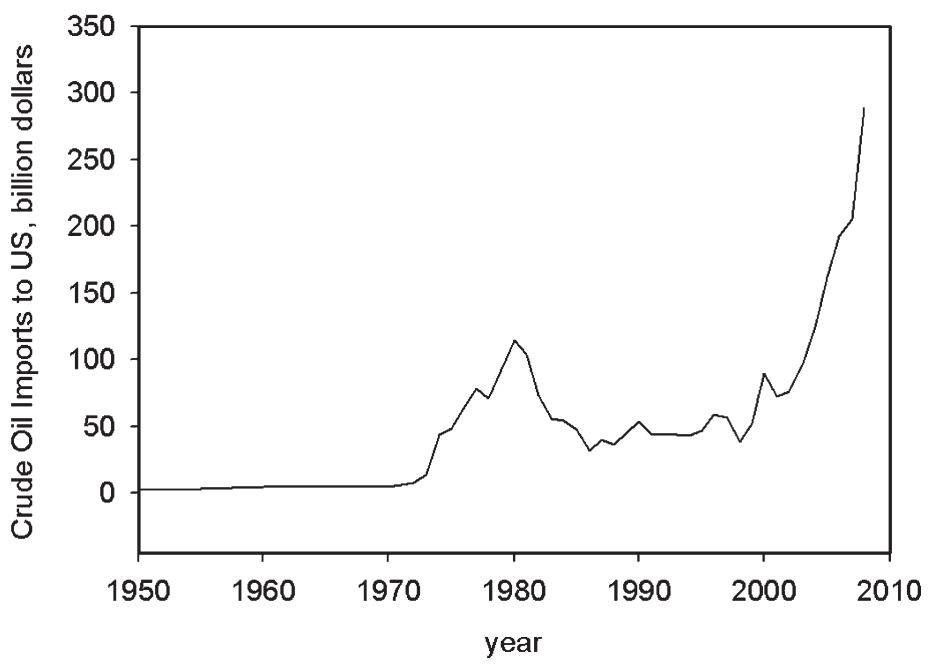

Figure 1. Inflation-adjusted annual value of crude oil imports into the United States in billions from 1950 to 2008 (in 2000 dollars). (From EIA, Annual Energy Review 2008, U.S. Department of Energy, Washington, DC, 2009.)

oil supply and accompanying oil price spikes can have significant negative impacts on the global economy. ${ }^{26}$ While the interrelationships between the business cycle and petroleum price are complicated and not easily resolved, ${ }^{36}$ Brown $^{6}$ reports that 9 of the past 10 U.S. recessions since 1945 were preceded by significant oil price spikes. The relationships between oil price and the health of the economy suggest that current high and unstable oil prices could have broad implications for economic stability.

The high oil prices of 2008 led to the transfer of nearly $\$ 1$ trillion to members of OPEC, the Organization of the Petroleum Exporting Countries. ${ }^{17}$ National oil companies in OPEC and other countries, such as Saudi Aramco (Saudi Arabia), the National Iranian Oil Company (Iran), Petrochina (China), Petrobras (Brazil), and Gazprom (Russia), control approximately $90 \%$ of the world's oil reserves and $75 \%$ of global oil production - similar numbers apply for natural gas. ${ }^{69}$

In conjunction with these trends, growing military intervention to ensure access to foreign oil has amplified the threat of international conflict. There is growing consensus in the economic and military communities that oil played a large part in the U.S.-led invasion of Iraq in 2003.4,26,44,50 Iraq has the third largest oil reserves globally at 115 billion barrels ( 9\% of global crude oil reserves), ranking below only Saudi Arabia and Iran. ${ }^{16}$ The full monetary cost of the Iraq war is projected by Stiglitz and Bilmes ${ }^{58}$ to range between $\$ 2.7$ and $\$ 5$ trillion and the conflict has resulted in between 90,000 and 800,000 violent deaths of Iraqi civilians and more than 4000 U.S. military deaths since 2003. ${ }^{63}$

As a corollary to the invasions of Iraq, ongoing U.S. military activities in Afghanistan are also motivated, in part, by proposed pipeline installation for transportation of oil and gas from Central Asia to the Indian Ocean. ${ }^{24,53,61}$ In that region, Kazakhstan contains three of the world's 10 largest giant oil fields (newly discovered), and they are now Chevron's leading source of petroleum, which is 
exported via pipelines heading west through Georgia. ${ }^{38,39,56}$ In U.S. Congressional testimony in 2006, Steven Mann, Principal Deputy Assistant Secretary for South and Central Asian Affairs at the State Department, clearly outlined U.S. intentions concerning energy in the Afghanistan region:

\begin{abstract}
"Since the independence of the new Caspian states 15 years ago, the United States has been in the forefront of oil and gas development in the region, and our efforts are paying off." "With the completion of the first phase of the EastWest Energy Corridor [through Georgia], we must now press on with the second phase of supporting new energy routes out of Central Asia." "The United States and the countries of the broader region share an interest in the free movement of energy, people, goods, and information from the Kazakh steppes to the Indian Ocean. We want not only to support economic development along a north-south axis, but also afford Afghanistan access to a wider world, thus becoming a bridge, not a barrier." 61
\end{abstract}

In addition to these two costly military ventures with significant relationships to energy resources, costly military security for global oil transportation includes protection of unstable maritime oil transit routes, which has been recently estimated to cost between $\$ 104$ and $\$ 138$ billion per year. ${ }^{11,12,19}$

Serious energy-related security issues also arise from the fact that international terrorism has been supported by tens of millions of dollars from the sale of Middle Eastern oil., ${ }^{77}$ Some of this money is thought to have been used to support the September 11, 2001 "9/11" terrorist attacks on the United States, ${ }^{47}$ although it is recognized that relatively little money was actually required to carry out most terrorist attacks in the last 10 years. ${ }^{67}$

These various challenges for the petroleum economy consisting of limited and fragile supply, wealth transfer, contribution to national deficits, costly military operations, and terrorism are all serious national security and economic issues. These issues have stimulated support for the development of alternative energy sources. ${ }^{14,71}$ Biomass resources are of particular importance because they can be converted to liquid fuels to substitute for petroleum which can be used in existing infrastructure with limited modification. The U.S. Energy Independence and Security Act of 2007 (EISA) mandates that 36 Bgal of biofuels be produced annually by 2022, of which $15 \mathrm{Bgal} /$ year are to be grain ethanol, $16 \mathrm{Bgal} /$ year are to be cellulosic ethanol, and $5 \mathrm{Bgal}$ are to be other advanced renewable fuels. Furthermore, the U.S. Air Force, the world's single largest consumer of petroleum, recently announced a plan to substitute $50 \%$ of their fuel use with alternative fuels, with particular emphasis on biofuels. ${ }^{3}$ Continued expansion of the biofuel industry will place greater demands on agricultural productivity and efficiency.

While limited energy supply is increasingly problematic, the impacts of atmospheric emissions from fossil-based energy sources on global climate change are becoming well established. ${ }^{31}$ Anthropogenic climate change from greenhouse gas (GHG) emissions from burning fossil fuels will impact agriculture in a number of ways. Some of the changes that will have negative impacts on agriculture include higher average night-time temperatures, ${ }^{51}$ greater frequency of heat waves, heavy rainfall events, destructive storms, and regional droughts. ${ }^{35}$ In addition, rising sea level has the potential to submerge coastal agricultural regions, decreasing the availability of fertile agricultural land. Finally, rising temperature is 
contributing to the global disappearance of glaciers that threatens the water supply of regions dependent on glacial meltwater for irrigation to support agricultural productivity. 49,65

The sum of these challenges for agriculture may be quite significant in the near-term future. Commodity prices will rise, and these price increases will stimulate adoption of more efficient production techniques as well as expansion of agricultural systems. Nutrient efficiency research will provide new information that will permit these adjustments to be made, which otherwise would not be possible with lower food and biofuel prices.

\section{Agricultural Nutrient Use Efficiency and Biofuels}

Energy price increases raise both the cost of field operations and the prices of crop inputs. Most $\mathrm{N}$ fertilizers are manufactured from natural gas or petroleum, so their costs will obviously rise with oil prices. Even though potash and phosphate are not manufactured from fossil energy, substantial amounts of energy are required in their extraction and processing, and their prices have also recently followed oil prices (Figure 2a). The primary nutrient applied in the United States is $\mathrm{N}$ (Figure $2 \mathrm{~b}$ ), and its price is most closely related to oil price. Therefore, sustained oil prices above $\$ 100$ per barrel will lead to fertilizer prices substantially higher than previously experienced, and drive investment in practices to limit fertilizer expenditures and increase nutrient use efficiency.

Improved management has contributed to recent gains in nutrient use efficiency for corn in the United States to the extent that on average 37\% of applied $\mathrm{N}$ is now taken up by the crop. From 1980 to 2000, N application remained relatively constant at $146 \mathrm{~kg} \mathrm{ha}^{-1}$ (Figure 2c) while the partial factor productivity (kg grain yield per $\mathrm{kg}$ of $\mathrm{N}$ applied) increased by $36 \%$ (from 42 to $57 \mathrm{~kg} \mathrm{~kg}^{-1}$ ). ${ }^{8}$ Increasing agricultural nutrient use efficiency will also reduce the negative climate impact of crop production.

GHG emissions from agriculture are a large positive source of global warming potential. In 2005, nonfossil fuel emissions from global agriculture contributed $10 \%-12 \%$ of total of anthropogenic GHG emissions, with methane $\left(\mathrm{CH}_{4}\right)$ contributing a little over half of emissions and nitrous oxide $\left(\mathrm{N}_{2} \mathrm{O}\right)$ emissions contributing the majority of the remainder. ${ }^{57}$ These agricultural emissions contributed roughly $50 \%$ of global methane emissions and $60 \%$ of nitrous oxide emissions. Methane is produced when organic materials decompose in oxygen-deprived conditions, with significant sources from digestion in ruminant livestock, manure, and flooded rice. Nitrous oxide, on the other hand, is produced by the microbial transformation of $\mathrm{N}$ in soil and manure. Global agricultural $\mathrm{N}_{2} \mathrm{O}$ emissions are projected to increase by $35 \%-60 \%$ by 2030 due to increased $\mathrm{N}$ fertilizer use and increased animal manure production. In the United States, however, synthetic $\mathrm{N}$ applications are projected to remain relatively constant, and increases in $\mathrm{N}_{2} \mathrm{O}$ emissions are projected mainly from manure. ${ }^{57}$ Large and uncertain net fluxes of carbon dioxide from global agriculture are not thought to contribute much to net GHG emissions from agriculture overall.

In addition to biogenic GHG emissions, additional GHG emissions from production and application of cropping inputs must also be considered. After totaling net biogenic and fossil fuel inputs for a corn grain cropping systems in U.S. 
a.

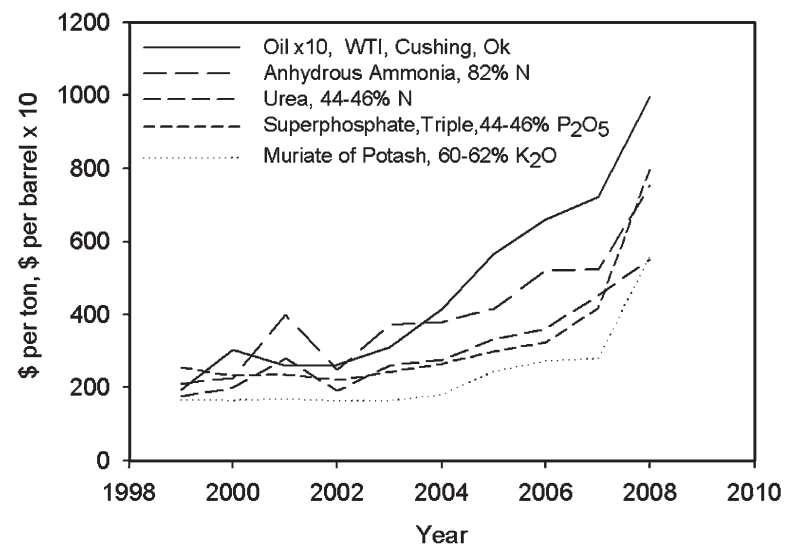

b.
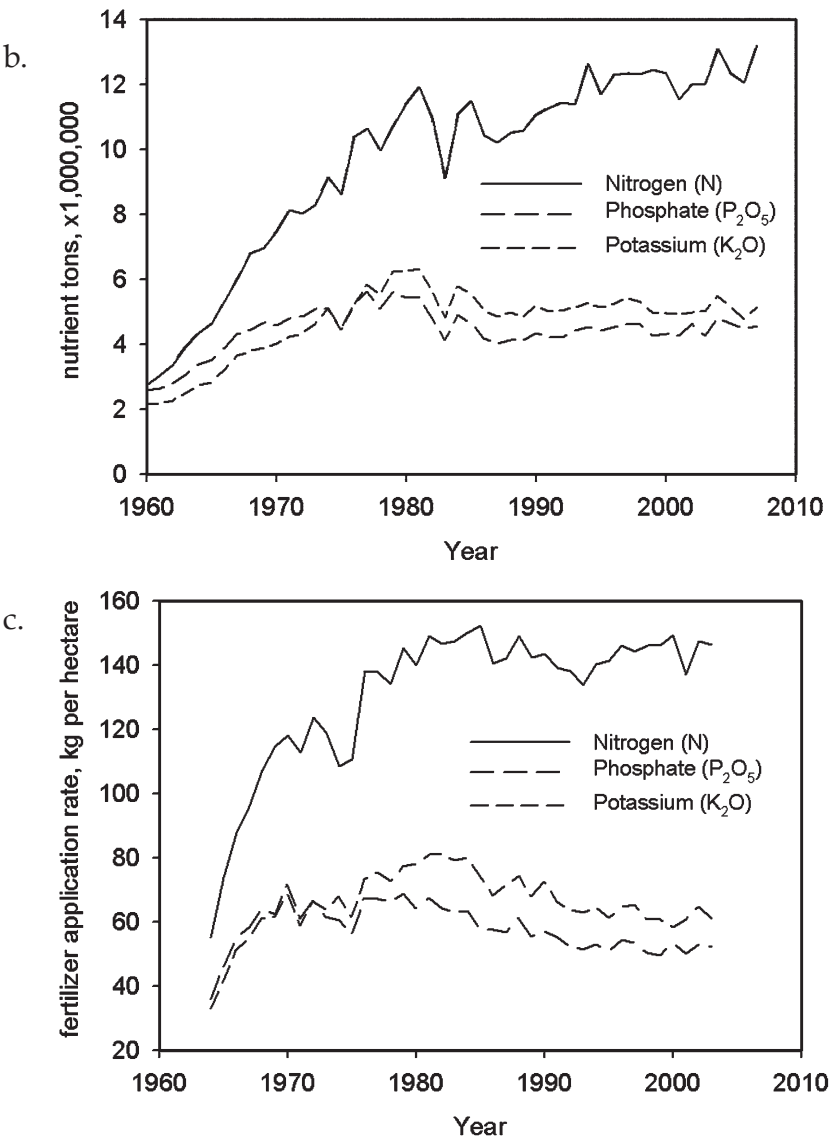

Figure 2. Average annual fertilizer and oil prices (a), total fertilizer consumption in the United States (b), and average fertilizer application rates per hectare for corn (c). (From EIA, Official Energy Statistics from the U.S. Government. Accessed at http://tonto.eia. doe.gov ; November 2009; ERS [Economic Research Service], USDA, U.S. Fertilizer Use and Price. Accessed at http://www.ers.usda.gov/Data/FertilizerUse/ ; November 2009; USDA [United States Department of Agriculture], Agricultural Prices Supplement, August 2009. Accessed at http://usda.mannlib.cornell.edu/usda/current/AgriPricSu/ AgriPricSu-08-05-2009.pdf ; November 2009.) 
Table 1. Energy Inputs and Direct GHG Emissions from an Average Corn Cropping System in the Midwest, Assuming Soil Carbon Dynamics Are Neutral

\begin{tabular}{lrr}
\hline & Energy Inputs, $\%$ & GHG Emissions, $\%$ \\
\hline Nitrogen fertilizer & 39.7 & 15.0 \\
$\mathrm{~N}_{2} \mathrm{O}$ emissions from $\mathrm{N}$ fertilizera. & \\
$\quad$ volatilization, leaching, runoff & & 35.5 \\
$\mathrm{~N}_{2} \mathrm{O}$ emissions from crop and biomass N: & - & \\
$\quad$ crop residue, roots, manure & - & 12.7 \\
Phosphorus fertilizer & 2.2 & 3.2 \\
Potassium fertilizer & 3.7 & 1.5 \\
Lime & 0.2 & 6.3 \\
Herbicides & 11.5 & 5.2 \\
Insecticides & 0.5 & 0.2 \\
Seed & 1.2 & 0.6 \\
Gasoline & 3.8 & 1.7 \\
Diesel & 16.2 & 8.7 \\
LPG & 8.3 & 3.4 \\
Natural gas & 4.8 & 1.7 \\
Electricity & 6.0 & 3.1 \\
Farm machinery & 2.0 & 0.9 \\
Total & 100.0 & 100.0 \\
\hline
\end{tabular}

Source: Liska, A. J. et al., J. Ind. Ecol., 13, 58, 2009.

a. Of synthetic $\mathrm{N}$ fertilizer applied, $1.33 \%$ is lost as $\mathrm{N}_{2} \mathrm{O}$.

Emissions from "fertilizer[s]" are from fossil fuel use in upstream production.

Corn Belt, $\mathrm{N}_{2} \mathrm{O}$ emissions from fertilizer $\mathrm{N}$ inputs (based on IPCC emission factors) were found to be roughly $36 \%$ of net GHG emissions ${ }^{32,42}$ (Table 1 ). Applications of $\mathrm{N}$ are also a significant fraction of energy inputs for corn grain production accounting for roughly $40 \%$ of agricultural energy inputs. By improving $\mathrm{N}$ use efficiency, energy inputs and emissions can be reduced. Evidence suggests that $\mathrm{N}_{2} \mathrm{O}$ emissions can be reduced by $20 \%$ by increasing crop $\mathrm{N}$ use efficiency via crop management, by $10 \%$ via use of either soil $\mathrm{N}$ tests or fertilizer timing, and by $5 \%$ with the use of either nitrification and urease inhibitors or $\mathrm{N}$ fertilizer placement. ${ }^{9}$ Different types of $\mathrm{N}$ fertilizer may also have the potential to reduce $\mathrm{N}_{2} \mathrm{O}$ emissions. Furthermore, efficient $\mathrm{N}$ use can be improved by adjusting application rates using GIS-based precision estimates of crop needs.

Crops accumulate their biomass carbon from atmospheric carbon dioxide and have the potential to be an energy source that does not contribute to net growth in atmospheric GHGs. If bioenergy is not to significantly contribute to GHG emissions, efficient collection and conversion to liquid forms is required for minimal use of fossil fuels. Ethanol production from corn grain in the United States and from sugarcane in Brazil are models for increased utilization of agricultural resources to meet societies' energy needs while reducing GHG emissions relative to the gasoline they replace (although indirect GHG contributions of both gaso- 
line and biofuel production are not yet accurately accounted for in current analytical methods). ${ }^{41}$ Significant research and development efforts are also underway to better utilize biomass resources for transportation fuels via production of cellulosic ethanol, and other so-called "second-generation" biofuels, although these systems are not yet profitable. ${ }^{43}$

Biofuel production is a "system of systems" 34 composed of distributed independent complex systems for crop production, biomass transportation, biorefining, co-product use, fossil fuel production and delivery, fertilizer and chemical inputs, and end-use vehicle systems. The efficiency of the overall biofuel production system can be analyzed using life cycle assessment (LCA), which is used to compare biofuel performance with fossil fuel systems. In addition, LCA enables the environmental impacts of a production system to be analyzed to identify areas for improvements in efficiency. ${ }^{25}$

The life cycle efficiency of biofuel production is primarily analyzed in terms of energy efficiency and net GHG emissions. ${ }^{42,43}$ Crop production contributes approximately $50 \%$ of positive life cycle emissions. ${ }^{42}$ In the past and now, research into the life cycle energy efficiency of biofuel production systems (particularly corn-ethanol) has been marked by conflicting results, but greater consensus from recent research shows positive energy and GHG benefits are derived from biofuel production and use. ${ }^{1,5,23,40,42}$ The EISA legislation now requires that biofuels must reduce life cycle GHG emissions, including indirectly caused emissions, compared to fossil fuels. Comparisons of the indirect GHG emissions resulting from gasoline production and corn-ethanol production are still primitive. ${ }^{41}$ EISA requires that corn-ethanol must reduce emissions by $20 \%$ compared to gasoline, but the precise methodologies for these life cycle calculations are still under development. Other recent state legislation, such as in California, will restrict market access if biofuels do not meet life cycle GHG emissions reduction targets.

Recent improvements in biorefinery energy efficiency have greatly influenced the life cycle energy efficiency of corn-ethanol production. ${ }^{42}$ In 2001 , survey data reported that energy inputs for the biorefinery were $13.9 \mathrm{MJ} \mathrm{L}^{-1}$ (primarily coal and natural gas) and comprised $67 \%$ of life cycle energy inputs. ${ }^{23}$ Since 2001 , the U.S. corn-ethanol industry has significantly expanded with new more efficient production capacity, composed primarily of natural gas powered dry mill biorefineries (Figure 3). Survey data from 2006 documents the increasing average energy efficiency of the industry, with biorefinery energy inputs reduced to 7.7 MJ $\mathrm{L}^{-1}$, contributing $56 \%$ to life cycle energy inputs. ${ }^{42,52}$ Use of recent data suggest that corn-ethanol has a net energy return of 1.6 units of energy per unit of energy invested. ${ }^{42}$ Furthermore, compared to gasoline, corn-ethanol has been shown to reduce direct GHG emissions by approximately $47 \%$ on average ${ }^{5,40}$; this estimate, however, does not include emissions from indirect land use change. ${ }^{55}$

Other agricultural biofuel production systems are under development, but most other systems suffer from relatively lower energy yield per hectare and lower energy yield per unit of nutrient applied compared with ethanol produced from corn and sorghum grain. For example, in the United States, soybean-biodiesel produces on average $15 \%$ of the biofuel volume per hectare compared with corn-ethanol. ${ }^{43}$ Correcting for energy density differences, soybean-biodiesel yields $23 \%$ of the gross energy yield of corn-ethanol on average. Cellulosic ethanol produced from crop residues and perennial grasses is currently under devel- 


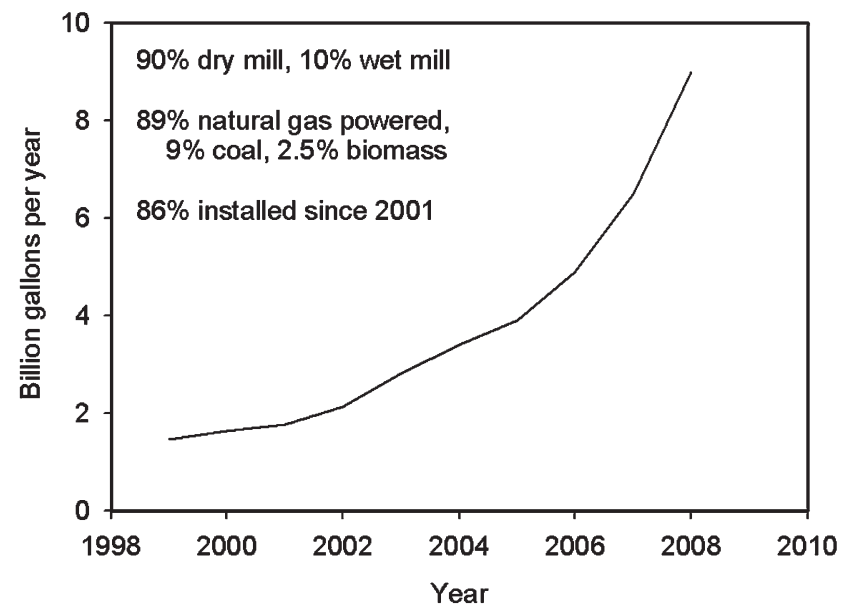

Figure 3. Increasing ethanol production capacity utilizing corn grain in the United States. Total installed capacity in 2009 is $12.5 \mathrm{Bgal} /$ year. Industry statistics provided by Cooper. (From Cooper G., Personal communication, Renewable Fuels Association, Washington, DC, 2009.)

opment, and only a very limited production capacity is installed. Ethanol from sweet sorghum provides an alternative cropping system that shows potential to be competitive with corn grain. ${ }^{70}$

State-level production statistics and field trial data provide a comparison among these selected ethanol production systems in Nebraska (Table 2). Gross energy yield per hectare as ethanol was found to range from 10 to $95 \mathrm{GJ} \mathrm{ha}^{-1}$, with use of both corn grain and residue being the most productive system. Despite this wide range in productivity per area, the $\mathrm{N}$ use efficiency only varies from 0.47 to 0.70 , with an average of $0.586 \mathrm{GJ}$ ethanol per $\mathrm{kg} \mathrm{N}$ applied (Figure 4). As a stand-alone component, residue is the least productive system, but had the highest efficiency, while the most productive system (corn grain plus residue) only had a slightly higher efficiency than the average. Ethanol from grain sorghum and switchgrass had $\mathrm{N}$ use efficiencies below average for the five systems. Of these systems, sweet sorghum stood out as having the third highest energy yield, but field trials found no significant response to $\mathrm{N}$ applications over a 2 year trial period..$^{70}$ This response is suggested because of a more gradual rate of nutrient uptake in sweet sorghum, and $\mathrm{N}$ uptake later in the season compared with the grain crops. This is significant because it indicates that with appropriate crop rotations, a relatively high yielding system could exist with limited $\mathrm{N}$ fertilizer inputs. Sweet sorghum should be researched further in the future to explore the lower limits of $\mathrm{N}$ applications for high-yield biofuel systems.

Nutrient use efficiency is just one important aspect in defining the life cycle GHG emissions and energy efficiency of biofuel production systems. Another important consideration for nutrient use and GHG emissions is changes in soil carbon. ${ }^{37,68,70}$ Removing crop residue for biofuels also removes soil phosphorus $(\mathrm{P})$ and potassium $(\mathrm{K})$; one metric ton of corn residue harvested removes $8 \mathrm{~kg}$ of $\mathrm{N}$, $0.79 \mathrm{~kg}$ of $\mathrm{P}$, and $6.74 \mathrm{~kg}$ of $\mathrm{K} .{ }^{28}$ If ethanol production from crop residue and energy crops such as switchgrass is pursued in the future, appropriate nutrient replacement will be vital to maintain crop productivity. ${ }^{66}$ 
Table 2. Nutrient Use Efficiency of Selected Cropping Systems for Ethanol Production in Nebraska

\begin{tabular}{|c|c|c|c|c|c|}
\hline & $\begin{array}{r}\text { Nitrogen } \\
\text { Rate, } \\
\mathrm{kg} \mathrm{ha}^{-1}\end{array}$ & $\begin{array}{r}\text { Biomass } \\
\text { Yield, } \\
\text { Mg ha-1 }^{-1}\end{array}$ & $\begin{array}{r}\text { Biofuel } \\
\text { Conversion } \\
\text { Efficiency, } \\
\mathrm{LM} \mathrm{g}^{-1}\end{array}$ & $\begin{array}{r}\text { Gross } \\
\text { Energy } \\
\text { Yield, } \\
\text { GJ ha }{ }^{-1}\end{array}$ & $\begin{array}{r}\text { Nutrient } \\
\text { Use } \\
\text { Efficiency, } \\
\left(\mathrm{GJ} \mathrm{kg}^{-1}\right) \mathrm{N}\end{array}$ \\
\hline $\begin{array}{l}\text { Corn residue, } \\
20 \% \text { removal }\end{array}$ & 14.4 & 1.62 & 294 & 10.0 & 0.70 \\
\hline Switchgrass & 78.1 & 7.10 & 294 & 44.0 & 0.56 \\
\hline Grain sorghum & 96.0 & 4.29 & 501 & 45.3 & 0.47 \\
\hline Sweet sorghum & 0 & 3.54 & 665 & 49.7 & - \\
\hline Corn grain & 144.0 & 8.09 & 501 & 85.4 & 0.59 \\
\hline $\begin{array}{l}\text { Corn grain }+ \\
\quad \text { residue, 20\% }\end{array}$ & 158.4 & 9.70 & - & 95.4 & 0.63 \\
\hline
\end{tabular}

a. Partial factor productivity. All yields are on a dry matter basis. Corn grain and residue yields ${ }^{46}$ (2004- 2006) and conversion of grain to ethanol and ethanol energy density $\left(21.1 \mathrm{MJ} \mathrm{L}^{-1}\right)$ were previously reported. ${ }^{42}$ Nitrogen rates for corn were previously reported ${ }^{21}$ and $20 \%$ residue removal is allocated $\mathrm{N}$ applied for $10 \%$ of above ground biomass. Switchgrass yields in NE were also previously reported, ${ }^{54}$ and it is assumed that $\mathrm{N}$ will be applied at the recommended rate of $11 \mathrm{~kg} \mathrm{~N} \mathrm{Mg}^{-1}$ biomass yield. ${ }^{66}$ Conversion yield for switchgrass and residue is $70 \mathrm{gal} / \mathrm{ton}$ based on Iogen technology from a DOE-funded facility (http://www.energy.gov/news/4827.htm ). Grain sorghum yields $^{46}$ (2004-2006) and N application rates ${ }^{21}$ were for Nebraska. Sweet sorghum theoretical yield is based on field studies and estimated from $80 \%$ juice extracted and brix reading with the Simon cv. in $2008 .^{70}$ The corn plus residue system assumes additional $\mathrm{N}$ rate for the $20 \%$ of $\mathrm{N}$ removed.

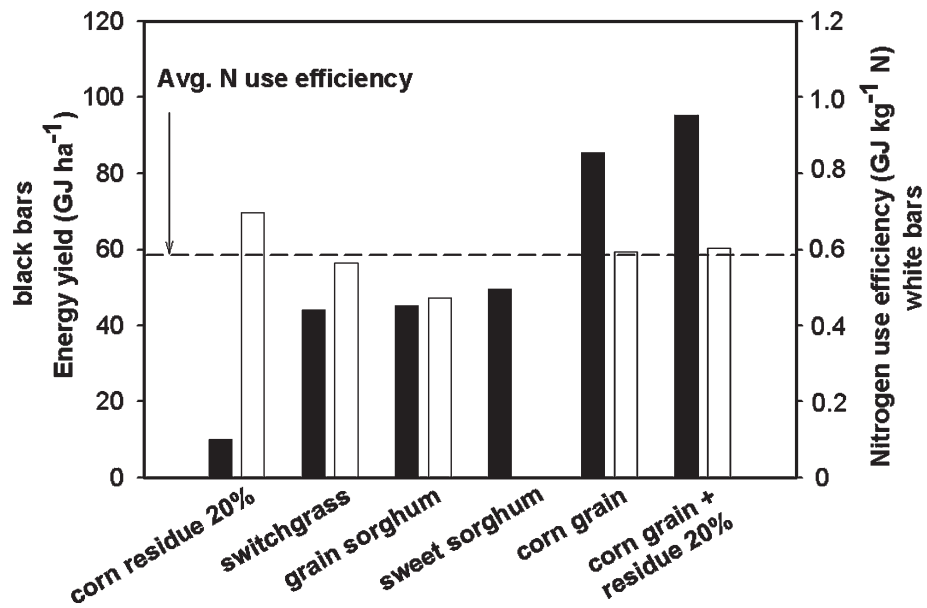

Figure 4. Bioenergy productivity versus nutrient use efficiency: ethanol gross energy yield (GJ ha ${ }^{-1}$, black bars) and nitrogen use efficiency (GJ kg-1 $\mathrm{N}$ applied, white bars) for selected cropping systems for ethanol production in Nebraska. Average $\mathrm{N}$ use efficiency (partial factor productivity) for the five systems reporting $\mathrm{N}$ application is shown with a dashed line. 


\section{Land Limitations and Global Agricultural Production}

Pressure for increased agricultural production over the next 40 years will come from three sources: world population growth, per capita income growth, and demand for biofuels. Population growth alone is projected to require a one-third increase in crop production, and increased demand for livestock products, made possible by higher incomes, is expected to further increase the required production to approximately 50\% above current levels by 2050 (Figure 5a). In addition, biofuel production will result in yet additional demands on agricultural resources. Yet, there is little potential for increasing the critical agricultural resources necessary to provide this additional biomass, making it crucial that more efficient production techniques be developed and adopted.

a.

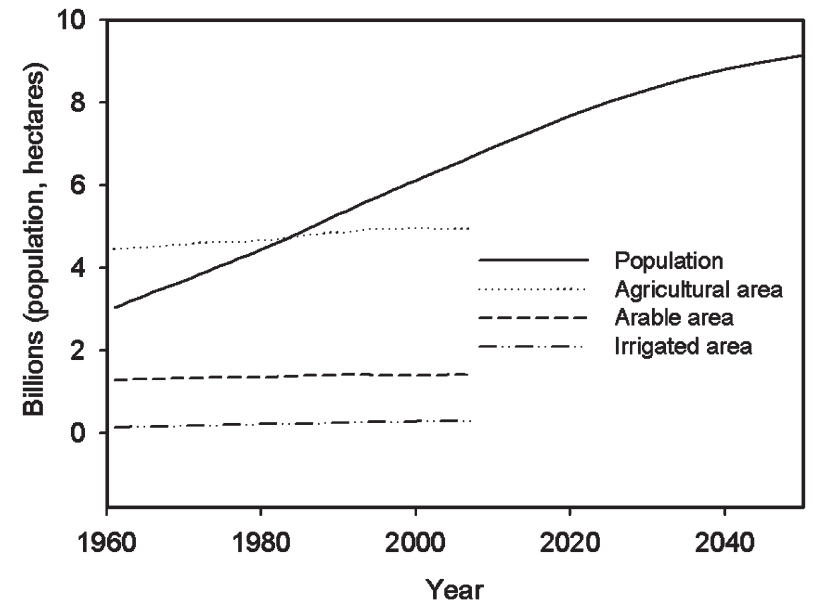

b.

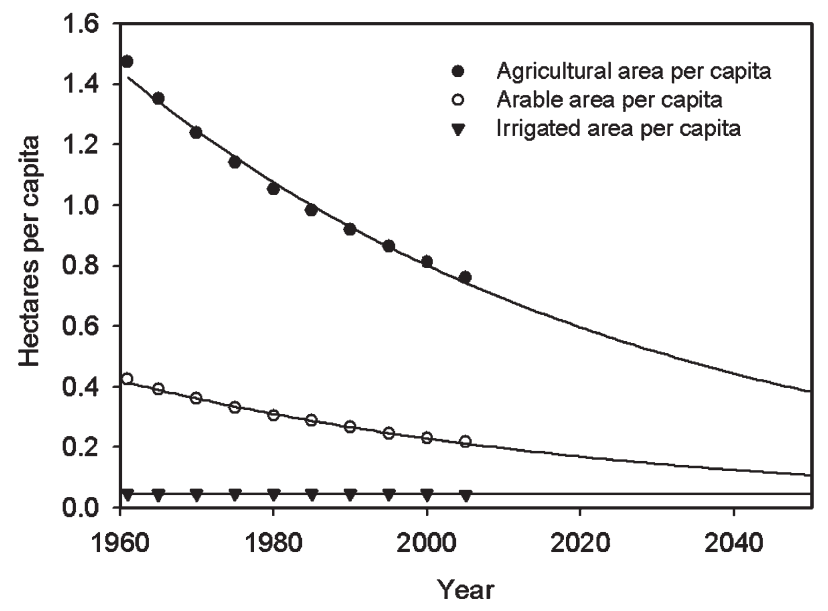

Figure 5. Trends and projections for global population and agriculture land resources (a) and agricultural area per capita (b). (From FAO [Food and Agriculture Organization of the United Nations], FAOSTAT; available at http://faostat.fao.org ; accessed November 24, 2009; UN [United Nations], World Population Prospects: The 2008 Revision; available at http://esa.un.org/unpp ; accessed November 24, 2009.) 
Crops for biofuel production were grown on about 36 million hectares (Mha) around the globe, or $2.5 \%$ of the world's arable land in $2008 .{ }^{60}$ Comparable figures for current biofuel area from another recent report are 41 Mha $(2.8 \%) .{ }^{48}$ Projections of future growth in land use for biofuel production are difficult to make, because of uncertainty about the relative prices of food and energy and uncertainty about policies that either encourage or discourage biofuel production. The $\mathrm{UNEP}^{60}$ reports projections to $60-80 \mathrm{Mha}$, or even $166 \mathrm{Mha}$, by 2020, which are equivalent to $4 \%-11 \%$ of the current stock of arable land, or $1 \%-3 \%$ of total agricultural land.

Recent and potential increases of biofuel crops in Brazil and Indonesia are dramatic. Cropping area devoted to sugarcane in Brazil has increased from 7 to 9 Mha between 2007 and 2008, now constituting about 15\% of the 60 Mha of arable land in Brazil. ${ }^{60}$ This upward trend will continue, though the government intends to limit the expansion into sensitive ecosystems. Soybeans, also used in part for biodiesel, occupied about 23 Mha in 2005, and are expected to occupy the majority of an additional 60 Mha that will likely be converted from savannah to crop land. The Indonesian government intends that the current 6 Mha of oil palm be augmented by another 18-20 Mha, ${ }^{33}$ with about two-thirds of this to be planted on land currently covered by rainforests.

It is clear that world agricultural land resources will not increase much, based on the experience of the last 10 years (Figure 5a). Of the approximately 5 Bha of total agricultural land, only about 1.4 Bha or $28 \%$, is arable. Irrigated land has increased only about a half a percent per year, arable land less than $0.2 \%$ per year, while total agricultural land has actually declined.

Population has of course increased during this time, resulting in the very dramatic decreases in land per capita (Figure 5b). If the per capita land resource base continues to decline along the trend of the last 50 years, a great deal of pressure will be placed on agricultural research to achieve the kind of productivity improvement that will be needed.

Water is another critical component of the agricultural resource base, one that will more likely decline rather than increase with population. Irrigated land, as noted above, has increased very little over the past decade. Aquifers are being depleted, snowpack's and glaciers are declining, and climate change may reduce rainfall in many regions, while contributing to higher rainfall, and more extreme rainfall events in other areas. ${ }^{35}$ It is clear that in the case of agricultural water, efficiency will have to increase if there is to be any chance of providing the needed production increases.

As opposed to land, global per capita consumption of fertilizer materials has increased over the last 50 years, though irregularly (Figure 6a). The increased fertilizer use over the past decade has helped make possible a slight per capita increase in agricultural production over the past two decades. With this increase in usage, worldwide average $\mathrm{N}$ efficiency has begun to decline, while phosphorus and potassium efficiencies have stabilized after realizing improvements over the previous 2 or 3 decades (Figure 6b). Figures reported here are measured in terms of fertilizer materials rather than in fertilizer elements; therefore, any change in the mix of materials over this period may slightly distort the trends in fertilizer elements.

It appears that quantities of land and water allocated to crop production will not increase much in the future, whereas crop nutrients and energy inputs will 
a.

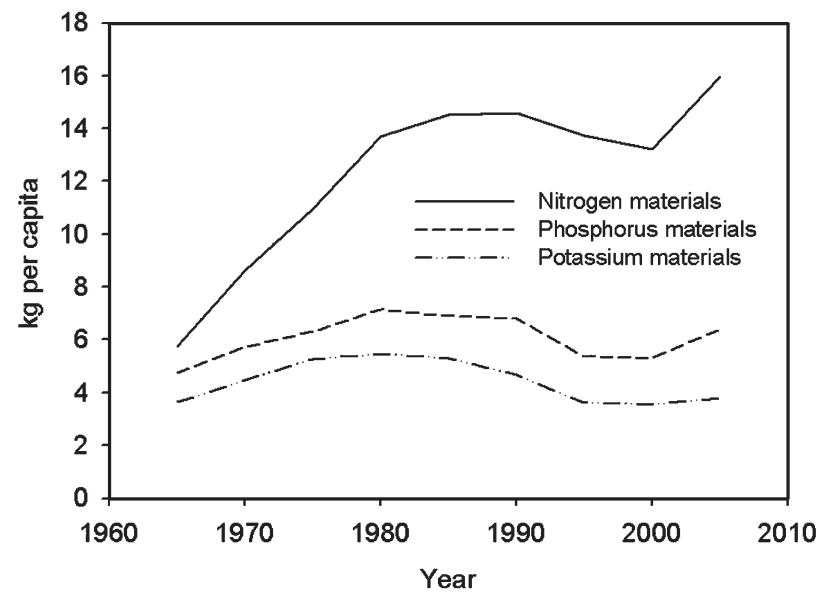

b.

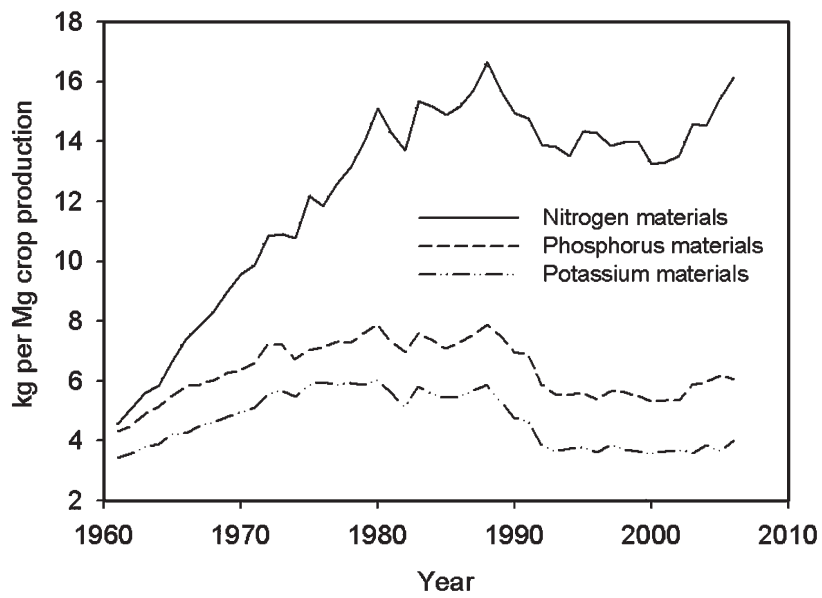

Figure 6. Global fertilizer materials consumption per capita (a) and fertilizer materials per ton of crop production (b) derived from References 22 \& 59. (From FAO [Food and Agriculture Organization of the United Nations], FAOSTAT; available at http:/ / faostat.fao.org ; accessed November 24, 2009; UN [United Nations], World Population Prospects: The 2008 Revision; available at http://esa.un.org/unpp ; accessed November 24, 2009.)

be more elastic in supply. But increases in land, energy inputs, and nutrients will entail increases in GHG emissions, making it critical that the required increase in output be achieved with maximum possible efficiency of input use.

Land use change is a significant source of GHG emissions and a driver of climate change, being responsible for approximately $20 \%$ of global anthropogenic GHG emissions in the 1990s. ${ }^{31}$ These emissions result from the burning of forest and savanna biomass when those lands are converted to cultivated crop production, and from loss of soil carbon stocks when the land is cultivated. It is therefore likely that climate change policies will provide further barriers to the expansion of arable land, adding another source of urgency for improving efficiencies in crop production. ${ }^{41}$ Similarly, the GHG emissions related to fertilizer use, mentioned above, may lead to higher costs of nutrients or restrictions on the use of nutrients, adding incentives for generating improved efficiencies in nutrient use. 


\section{Conclusions}

Multiple lines of evidence point to a global oil economy that is increasing unstable, which has broad consequences for economic growth, international military activity, and the future costs of agricultural production. Energy and climate issues are stimulating the production of biofuels from agricultural products which has numerous implications for nutrient use. Climate change has multiple potentially serious impacts on agriculture as well. Growing demand for agricultural products, in conjunction with volatile weather and more costly cropping inputs will lead to greater pressure in the future to increase yields, while minimizing nutrient inputs. These trends will provide significant incentive to heavily invest in better management of nutrient applications in the future and to develop the science necessary to keep improving nutrient use efficiency while meeting new demands on agricultural production from both biofuels and population growth.

\section{References}

1. Anex R. and Lifset R. Post script to the corn ethanol debate: Reaching consensus? Journal of Industrial Ecology 13, 996, 2009.

2. Aleklett K., Höök M., Jakobsson K., Lardelli M., Snowden S., and Söderbergh B. The peak of the oil age-Analyzing the world oil production reference scenario in world energy outlook 2008. Energy Policy, 38, 1398, 2010.

3. Aviation Week. USAF Launches Major Biofuel Initiative. http://www.aviationweek.

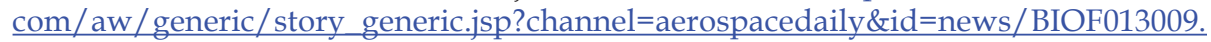
$\underline{\mathrm{xml}}(2009)$.

4. Bacevich A. The Limits of Power: The End of American Exceptionalism. Metropolitan Books, New York, 2008.

5. Bremer V. R., Liska A. J., Klopfenstein T.J., Erickson G. E., Yang H. S., Walters D.T., and Cassman K. G. Emissions savings in the corn-ethanol life cycle from feeding co-products to livestock. Journal of Environmental Quality 39, 472, 2010.

6. Brown S. P. A. Oil and the U.S. Macroeconomy, Federal Reserve. Bank of Dallas, June 2004. Presented at the WEAI Annual Meeting, July 2, 2004, Vancouver BC, 2004.

7. Burr J. M. and Collins R. O. Alms for Jihad: Charity and Terrorism in the Islamic World. Cambridge University Press, Cambridge, 2006.

8. Cassman K. G., Dobermann A., and Walters D. T. Agroecosystems, nitrogen-use efficiency, and nitrogen management. AMBIO 31, 132, 2002.

9. CAST (Council for Agricultural Science and Technology). Climate Change and Greenhouse Gas Mitigation: Challenges and Opportunities for Agriculture. Task Force Report 141, Ames, IA, 2004.

10. Cooper G. Personal communication. Renewable Fuels Association, Washington, DC, 2009.

11. Copulos M. R. The Hidden Costs of Imported Oil: An Update. National Defense Council Foundation, Arlington, VA, 2007.

12. Dancs A., Orisich M., and Smith S. The Military Cost of Securing Energy. National Priorities Project. http://www.nationalpriorities.org (2008).

13. Deffeyes K. Hubbert's Peak: The Impending World Oil Shortage. Princeton University Press, Princeton, Oxford, U.K. 2001.

14. Deutch J. and Schlesinger J. R. National Security Consequences of U.S. Oil Dependency. 
Council on Foreign Relations. Washington, DC, 2006.

15. EIA (Energy Information Administration). International Energy Outlook 2009. U.S. Department of Energy. Washington, DC, 2009.

16. EIA. Annual Energy Review 2008. U.S. Department of Energy, Washington, DC, 2009.

17. EIA. OPEC Revenues Fact Sheet. U.S. Department of Energy, 2009. Available at http:// www.eia.doe.gov/emeu/cabs/OPEC_Revenues/pdf.pdf

18. EIA. Official Energy Statistics from the U.S. Government. Accessed at http://tonto.eia. doe.gov, November 2009.

19. EIA. World Oil Transit Chokepoints. U.S. Department of Energy, 2008. Available at http://www.eia.doe.gov/cabs/World Oil Transit Chokepoints/pdf.pdf

20. Erisman J. W., Sutton M. A., Galloway J., Klimont Z., and Winiwarter W. How a century of ammonia synthesis changed the world. Nature Geoscience 1, 636, 2008.

21. ERS (Economic Research Service). USDA, U.S. Fertilizer Use and Price. Accessed at http://www.ers.usda.gov/Data/FertilizerUse/ (November 2009).

22. FAO (Food and Agriculture Organization of the United Nations). FAOSTAT. Available at http:/ / faostat.fao.org ; accessed November 24, 2009.

23. Farrell A. E., Plevin R. J., Turner B. T., Jones A. D., O'Hare M., and Kammen D. M. Ethanol can contribute to energy and environmental goals. Science 311, 506, 2006.

24. Foster J. A Pipeline through a Troubled Land: Afghanistan, Canada, and the New Great Energy Game. Foreign Policy Series, vol. 3, no. 1. Canadian Centre for Policy Alternatives, Ottawa, Ontario, Canada 2008.

25. Graedel T. and Allenby B. Industrial Ecology and Sustainable Engineering. Prentice-Hall, Englewood Cliffs, NJ, 2010.

26. Greenspan A. The Age of Turbulence: Adventures in a New World. Penguin, New York, 2008.

27. Höök H., Hirsch R., and Aleklett K. Giant oil field decline rates and their influence on world oil production. Energy Policy 37, 2262, 2009.

28. Hoskinson R. L., Karlen D. L., Birrell S. J., Radtke C. W., and Wilhelm W. W. Engineering, nutrient removal, and feedstock conversion evaluations of four corn stover harvest scenarios. Biomass \& Bioenergy 31, 126, 2007.

29. IEA (International Energy Agency). World Energy Outlook 2008, Paris, France, 2008.

30. IEA. World Energy Outlook 2009, Paris, France, 2009.

31. IPCC (Intergovernmental Panel on Climate Change). Climate Change 2007: The Physical Basis. Cambridge University Press, Cambridge, U.K., 2007.

32. IPCC. Eggleston H. S., Buendia L., Miwa K., Ngara T. and Tanabe K. 2006. IPCC Guidelines for National Greenhouse Gas Inventories. Prepared by the National Greenhouse Gas Inventories Programme. IGES, Hayama, Japan, 2006.

33. Jakarta Globe CPO Biodiesel Production Plan May Lift Regions, December 2, 2009. http://thejakartaglobe.com/business/ cpo-biodiesel-production-plan-may-lift-regions/345113

34. Jamshidi M. System of Systems Engineering. Wiley, New York, 2008.

35. Karl T. R., Melillo J. M., and Peterson T. C. (eds.). Climate Change Impacts in the United States. Cambridge University Press, Cambridge, U.K., 2009.

36. Kilian L. The economic effects of energy price shocks. Journal of Economic Literature 46, $871,2008$.

37. Lal R. and Stewart B. A. (eds.). Soil Quality and Biofuel Production. CRC Press, Boca Raton, FL, 2010. 
38. LeVine S. and Bush J. Kazakh oil: A war of nerves. Business Week, September 22, 2008.

39. LeVine S. The Oil and the Glory: The Pursuit of Empire and Fortune on the Caspian Sea. Random House, New York, 2007.

40. Liska A. J. and Cassman K. G. Response to Plevin: Implications for life cycle emissions regulations. Journal of Industrial Ecology 13, 508, 2009.

41. Liska A. J. and Perrin R. K. Indirect land use emissions in the life cycle of biofuels: Regulations vs. science. Biofuels, Bioproducts, and Biorefining 3, 318, 2009.

42. Liska A. J., Yang H. S., Bremer V. R., Klopfenstein T. J., Walters D. T., Erickson G. E., and Cassman K. G. Improvements in life cycle energy efficiency and greenhouse gas emissions of corn-ethanol. Journal of Industrial Ecology 13, 58, 2009.

43. Liska A. J. and Cassman K. G. Towards standardization of life-cycle metrics for biofuels: Greenhouse gas emissions mitigation and net energy yield. Journal of Biobased Materials and Bioenergy 2, 187-203, 2008.

44. Moran D. and Russell J. A. (eds.). Energy Security and Global Politics: The Militarization of Resource Management. Routledge, New York, 2008.

45. Morse E. L. Low and behold: Making the most of cheap oil. Foreign Affairs, September/ October, 2009.

46. NASS (National Agricultural Statistics Service), USDA, Quick Stats, State and County Data. Accessed at http://www.nass.usda.gov/ (November 2009).

47. NCTA (National Commission on Terrorist Attacks). The 9/11 Commission Report: Final Report of the National Commission on Terrorist Attacks upon the United States, Authorized Edition. W. W. Norton, New York, 2004.

48. OECD/FAO. OECD-FAO Agricultural Outlook 2008-2017, Paris, Rome, 2008. Available at http:// www.agri-outlook.org

49. Orlove B., Wiegandt E., and Luckman B. H. (eds.). Darkening Peaks: Glacier Retreat, Science, and Society. University of California Press, Berkeley, CA, 2008.

50. Pelletiere S. America's Oil Wars. Praeger Publishers, Westport, CT, 2004.

51. Peng S., Huang J., Sheehy J. E., Laza R. C., Visperas R. M., Zhong X., Centeno G. S. et al. Rice yields decline with higher night temperature from global warming. Proceedings of the National Academy of Sciences 101, 9971, 2004.

52. Perrin R. K., Fretes N., and Sesmero J. P. Efficiency in Midwest US corn ethanol plants: A plant survey. Energy Policy 37, 1309, 2009.

53. Rashid A. Taliban: Militant Islam, Oil and Fundamentalism in Central Asia. Yale University Press, New Haven, CT, 2000.

54. Schmer M. R., Vogel K. P., Mitchell R. B., and Perrin R. K. Net energy of cellulosic ethanol from switchgrass. Proceedings of the National Academy of Sciences, USA 105, 464, 2008 .

55. Searchinger T., Heimlich R., Houghton R. A., Dong F., Elobeid A., Fabiosa J. et al. Use of US croplands for biofuels increases greenhouse gases through emissions from landuse change. Science 319, 1238, 2008.

56. Simmons M. Twilight in the Desert: The Coming Saudi Oil Shock and the World Economy. Wiley, Hoboken, NJ, 2005.

57. Smith P., Martino D., Cai Z., Gwary D., Janzen H., Kumar P., McCarl B. et al. Agriculture. In Metz B., Davidson O. R., Bosch P. R., Dave R., Meyer L. A. (eds.). Climate Change 2007: Mitigation. Contribution of Working Group III to the Fourth Assessment Report of the Intergovernmental Panel on Climate Change. Cambridge University Press, Cambridge, U.K., 2007. 
58. Stiglitz J. E. and Bilmes L. J. The Three Trillion Dollar War: The True Cost of the Iraq Conflict. W.W. Norton, New York, 2008.

59. UN (United Nations). World Population Prospects: The 2008 Revision. Available at http:// esa.un.org/unpp ; accessed November 24, 2009, 2008.

60. UNEP (United Nations Environmental Programme). Towards Sustainable Production and Use of Resources: Assessing Biofuels, Paris, France, 2009.

61. U.S. Congress, House of Representatives. Assessing Energy and Security Issues in Central Asia. Hearing before the Committee of International Relations, July 25, 2006.

62. U.S. Congressional Research Service. The U.S. Trade Deficit, the Dollar, and the Price of Oil. U.S. Congressional Research Service, Washington, DC, 2008.

63. U.S. Congressional Research Service. Iraqi Civilian Deaths Estimates. U.S. Congressional Research Service, Washington, DC, 2008.

64. USDA (United States Department of Agriculture). Agricultural Prices Supplement, August 2009. Accessed at http://usda.mannlib.cornell.edu/usda/current/AgriPricSu/ AgriPricSu-08-05-2009.pdf (November 2009).

65. USGS (United States Geological Survey). Krimmel R.M. Glaciers of North America - Glaciers of the Conterminous United States, Glaciers of the Western United States. U.S. Geological Survey Professional Paper 1386-J-2, 2002.

66. Vogel K., Brejda J., Walters D. T., and Buxton D.R. Switchgrass biomass production in the Midwest: Harvest and nitrogen management. Agronomy Journal 94, 413, 2002.

67. Warde I. The Price of Fear: The Truth behind the Financial War on Terror. University of California Press, Berkeley, CA, 2007.

68. Wilhelm W. W., Johnson J. M. F., Karlen D. L., and Lightle D. T. Corn stover to sustain soil organic carbon further constrains biomass supply. Agronomy Journal 99, 1665, 2007.

69. World Bank. A Citizen's Guide to National Oil Companies: Part A. Technical Report, Washington, DC, 2008.

70. Wortmann C. S., Liska A. J., Ferguson R. B., Klein R. N., Lyon D. J., and Dweikat I. Dryland performance of sweet sorghum and grain crops for biofuel in Nebraska. Agronomy Journal 102, 319, 2010.

71. Zubrin R. Energy Victory: Winning the War on Terror by Breaking Free of Oil. Prometheus Books, Amherst, NY, 2009. 